\title{
Using self-reported height and weight in calculating body surface area: is it good practice in cardiovascular imaging?
}

\author{
Emer Sonnex*, Kate Mracek, Melissa L Grzeszczak, Richard Coulden \\ From 15th Annual SCMR Scientific Sessions \\ Orlando, FL, USA. 2-5 February 2012
}

\section{Summary}

Cardiac MR measurements of mass and volumes are normalized to patient height and weight. Many centers use self-reported BSA. This practice is easy and quick but is it accurate enough in this setting? We compared measured height and weight against self-reported figures, sub-dividing the data sets into sex and age to see if any group was more reliable in their self-reporting.

\section{Background}

Cardiac dimensions and volumes are widely used throughout cardiac imaging. Body mass index (BMI) and body surface area (BSA) can both be used but BSA is most validated. There are many formulae for calculating BSA but the Mosteller calculation is the easiest, can be performed on a basic calculator and has gained in popularity. BSA $=\left(\left(\right.\right.$ height $\mathrm{cm}^{*}$ weight $\left.\left.\left.\mathrm{kg}\right)<-2>/ 3600\right)\right)$. Many centers use self-reported height and weight for BSA calculation and subsequent normalization. Is this reliable?

\section{Methods}

All patients attending for cardiac MRI complete a safety questionnaire which also asks for self-reported height and weight. All cardiac MRI patients are also weighed and height measured (stocking feet) after changing into a hospital gown. We reviewed the height and weight of 238 patients over 4 months (97 females; 141 males; mean age 42 years, 18 stdev). We compared the selfreported values to those measured.

\section{Results}

$67 \%$ of patients mis-reported their weight by $1 \mathrm{~kg}$ or more (male $73 \%$; females $58 \%$ ), p $<0.001$ while $69 \%$ patients mis-reported their height by $1.25 \mathrm{cms}$ or more (68\% males; $70 \%$ females), $\mathrm{p}<0.001$. Half $(50 \%)$ of women and $37 \%$ of men under-estimated their weight while $66 \%$ of women and $51 \%$ of men under-estimated their height. Although 1 woman (76 years old) weighed $6.4 \mathrm{kgs}$ less than she reported, 28 women $(29 \%)$ weighed $2 \mathrm{kgs}$ or more than they self-reported with $10(10 \%)$ weighing $4 \mathrm{kgs}$ or more (range $4-12.3 \mathrm{kgs}$ ). Of these 10 patients, 7 were in the $40-50$ year age group. Interestingly 4 women thought they were taller $(>1.25 \mathrm{cms})$ and $58(60 \%)$ thought they were shorter. 15 men weighed $2 \mathrm{kgs}$ or less (range $2-15.4$ ) than they reported, 47 men (33\%) weighed $2 \mathrm{kgs}$ more than their self-reported weight with 21 (15\%) weighing more than $4 \mathrm{kgs}$ (range 4 - $24.9 \mathrm{kgs})$. Again, the largest group (34\%) was in the 40 - 50 year age group. 56 men $(40 \%)$ were $2.5 \mathrm{cms}$ (range $2.5-7 \mathrm{cms})$ shorter than they reported, $8(6 \%)$ were actually taller than they reported (range $2.5-6.5 \mathrm{cms}$ ).

\section{Conclusions}

Published review articles have indicated that women underestimate their weight and overestimate their height while older women are less reliable in their self-reported BSA. Men have also been reported to frequently overestimate their height. In our group, there was no set pattern and both men and women were inaccurate in their self-reported heights and weights. This was true for all age groups. Self-reported heights and weights are inaccurate with no clear age or sex pattern. Although it adds another step in the patient journey through the MRI department, all patients should have their height 
Table 1 Self-reported (SR) compared to measured (M) heights and weights

\begin{tabular}{|c|c|c|c|c|c|}
\hline Total $=238$ & Age & SR weight (kgs) & M weight (kgs) & SR height (cms) & M height (cms) \\
\hline mean & 42 & 79.91 & 81.57 & 168.45 & 170.43 \\
\hline stdev & 18 & 24.87 & 25.49 & 11.1 & 10.94 \\
\hline minimum & 6 & 23.18 & 23.1 & 117.50 & 118 \\
\hline maximum & 85 & 171.82 & 169 & 192.5 & 197 \\
\hline \multicolumn{6}{|l|}{ female $=97$} \\
\hline female mean & 38 & 67.99 & 69.51 & 160.34 & 162.81 \\
\hline female stdev & 18 & 21.4 & 21.89 & 7.39 & 7.95 \\
\hline female minimum & 10 & 28.18 & 28.1 & 140 & 139 \\
\hline female maximum & 85 & 154.55 & 157.5 & 180 & 182 \\
\hline \multicolumn{6}{|l|}{ male $=141$} \\
\hline male mean & 45 & 88.11 & 89.86 & 174.04 & 175.67 \\
\hline male stdev & 19 & 23.81 & 24.52 & 9.69 & 9.57 \\
\hline male minimum & 6 & 23.18 & 23.1 & 117.5 & 118 \\
\hline male maximum & 79 & 171.82 & 169 & 192.5 & 197 \\
\hline
\end{tabular}

and weight measured before their cardiac MRI examination.

\section{Funding}

Not applicable.

Published: 1 February 2012

doi:10.1186/1532-429X-14-S1-P39

Cite this article as: Sonnex et al:: Using self-reported height and weight in calculating body surface area: is it good practice in cardiovascular imaging? Journal of Cardiovascular Magnetic Resonance 2012 14(Suppl 1): P39.

Submit your next manuscript to BioMed Central and take full advantage of:

- Convenient online submission

- Thorough peer review

- No space constraints or color figure charges

- Immediate publication on acceptance

- Inclusion in PubMed, CAS, Scopus and Google Scholar

- Research which is freely available for redistribution

Submit your manuscript at www.biomedcentral.com/submit
C Biomed Central 